\title{
Vaginal Adenoid Basal Carcinoma
}

National Cancer Institute

\section{Source}

National Cancer Institute. Vaginal Adenoid Basal Carcinoma. NCI Thesaurus. Code C40262.

A carcinoma that arises from the vagina and is characterized by the presence of nests of basaloid cells with focal glandular formations. 